\title{
Venture capital and the structure of capital markets Banks versus stock markets
}

Bernard S. Blacka \& Ronald J. Gilsonb1

a Columbia University School of Law, New York, NY 10027, USA

b Stanford University School of Law, Stanford, California 94305, USA and Columbia University School of Law, New York, NY 10027, USA

(Received June 1996; final version received November 1997)

\section{Abstract}

The United States has many banks that are small relative to large corporations and play a limited role in corporate governance, and a well developed stock market with an associated market for corporate control. In contrast, Japanese and German banks are fewer in number but larger in relative size and are said to play a central governance role. Neither country has an active market for corporate control. We extend the debate on the relative efficiency of bank- and stock market-centered capital markets by developing a further systematic difference between the two systems: the greater vitality of venture capital in stock market-centered systems. Understanding the link between the stock market and the venture capital market requires understanding the contractual arrangements between entrepreneurs and venture capital providers; especially the importance of the opportunity to enter into an implicit contract over control, which gives a successful entrepreneur the option to reacquire control from the venture capitalist by using an initial public offering as the means by which the venture capitalist exits from a portfolio investment. We also extend the literature on venture capital contracting by offering an explanation for two central characteristics of the U.S. venture capital market: relatively rapid exit by venture capital providers from investments in portfolio companies; and the common practice of exit through an initial public offering.

Key words: Venture Capital; Exit Strategy; IPO; Comparative Corporate Governance JEL Classifications: G23; G32

1 The authors are grateful for helpful suggestions from the editor and an anonymous referee, and from Anant Admanti, Erik Berglof, Stephen Choi, Kevin Davis, Uri Geiger, Victor Goldberg, Paul Gompers, Joseph Grundfest, Ehud Kamar, Michael Klausner, Joshua Lerner, Ronald Mann, Paul Pfleiderer, Mark Ramsayer, Charles Sabel, Allen Schwartz, and Omri Yadlin, and from participants in workshops at Columbia Law School, Harvard Law School, Stanford Law School, the Max Planck Institute (Hamburg, Germany), and the American Law and Economics Association. Research support was provided by Columbia Law School and the Roberts Program in Law and Business, Stanford Law School. We thank Laura Menninger, Nishani Naidoo, Annette Schuller, and Ram Vasudevan for research assistance. 


\section{Introduction}

Contrasting capital markets in the United States with those of Japan and Germany has become a commonplace activity. The United States has a large number of comparatively small banks that play a limited role in the governance of large corporations, and a well developed stock market with an associated market for corporate control that figures prominently in corporate governance. In contrast, Japanese main banks and German universal banks are few in number but larger in size, relative to Japanese and German firms, and are said to play a central corporate governance role in monitoring management (e.g., Aoki, 1994; Roe, 1994). Neither country has an active market for corporate control.

Advocates of bank-centered capital markets claim that this structure fosters patient capital markets and long-term planning, while a stock market-centered capital market is said to encourage short-term expectations by investors and responsive short-term strategies by managers (e.g., Edwards \& Fischer, 1994; Porter, 1992). Advocates of stock market-centered systems (e.g., Gilson, 1996) stress the adaptive features of a market for corporate control which are lacking in bank-centered systems, and the lack of empirical evidence of short-termism.

Paralleling the assessment of the comparative merits of stock market and bank-centered capital markets, scholars have also sought to explain how the United States, Germany, and Japan developed such different capital markets. Recent work has stressed that the characteristics of the three capital markets do not reflect simply the efficient outcome of competition between institutions, in which the most efficient institutions survive. The nature of the American capital market -- a strong stock market, weak financial intermediaries, and the absence of the close links between banks and nonfinancial firms said to characterize the Japanese and German capital markets -- reflects, at least in part, politics, history and path-dependent evolution, rather than 
economic inevitability (e.g., Black, 1990; Gilson, 1996; Roe, 1994). Much the same seems to be true of Germany and Japan (Hoshi, 1993; Roe, 1994). To be sure, competitively driven evolution hones efficiency, but institutions that emerge are shaped at critical stages by the random hand of events and the instrumental hand of politics.

In this article, we seek to contribute to two literatures. First, we extend the debate about the relative efficiency of bank- and stock market-centered capital markets by documenting and explaining a second systematic difference between the two systems: the existence of a much stronger venture capital industry in stock market-centered systems.

We define "venture capital," consistent with American understanding, as investment by specialized venture capital organizations (which we call "venture capital funds") in high-growth, high-risk, often high-technology firms that need capital to finance product development or growth and must, by the nature of their business, obtain this capital largely in the form of equity rather than debt. We exclude "buyout" financing that enables a mature firm's managers to acquire the firm from its current owners, even though in Europe, so-called "venture capital" firms often provide such financing -- more often, in many cases, than the financing that we call venture capital.

Other countries have openly envied the U.S. venture capital market and have actively, but unsuccessfully, sought to replicate it. We offer an explanation for this failure: We argue that a well developed stock market that permits venture capitalists to exit through an initial public offering (IPO) is critical to the existence of a vibrant venture capital market.

Understanding this critical link between the stock market and the venture capital market requires that we understand the implicit and explicit contractual arrangements between venture capital funds and their investors, and between venture capital funds and entrepreneurs. This 
brings us to our second contribution: We extend the literature on venture capital contracting by offering an explanation for two characteristics of the United States venture capital market. First, we explain the importance of exit -- why venture capital providers seek to liquidate their portfolio company investments in the near to moderate term, rather than investing for the long-term like Japanese or German banks. Second, we explain the importance of the form of exit: why the potential for the venture capital provider to exit from a successful start-up through an $I P O$, available only through a stock market, allows venture capital providers to enter into implicit contracts with entrepreneurs concerning future control of startup firms, in a way not available in a bank-centered capital market. Thus, we make explicit a functional link between private and public equity markets: The implicit contract over future control that is permitted by the availability of exit through an IPO helps to explain the greater success of venture capital as an organizational form in stock market-centered systems.

Section 2 of this article motivates the theoretical analysis by contrasting the venture capital markets in the United States and Germany. Section 3 develops the importance of exit from venture capital investments to the viability and structure of the venture capital industry. Exit serves two key functions. First, venture capital investors specialize in providing portfolio companies with a combination of financial capital, monitoring and advisory services, and reputational capital. The combination of financial and nonfinancial services loses its efficiency advantages as the portfolio company matures. Thus, recycling venture capital investors' capital through exit and reinvestment is jointly efficient for the provider and the portfolio company. Second, exit facilitates contracting between venture capital managers (persons with expertise in identifying and developing promising new businesses) and providers of capital to venture capital managers. The exit price gives capital providers a reliable measure of the venture capital 
manager's skill. The exit and reinvestment cycle also lets capital providers withdraw capital from less skilled venture capital managers or managers whose industry-specific expertise no longer matches the nature of promising start-up firms. It supports an implicit contract under which capital providers reinvest in the future limited partnerships of successful venture capital managers.

Section 4 focuses on the implicit contract over control between the entrepreneur and the venture capital fund. The potential to exit through an IPO allows the entrepreneur and the venture capital fund to enter into a self-enforcing implicit contract over control, in which the venture capital fund agrees to return control to a successful entrepreneur by exiting through an IPO. This implicit contract cannot readily be duplicated in a bank-centered capital market. Section 5 compares the predictions from our informal model to evidence about the success of venture capital in other countries, including Canada, Great Britain, Israel, and Japan. Section 6 considers alternative explanations for the observed international patterns of venture capital development, especially differences in legal rules. Some of these reasons may have predictive power, but none has enough power to displace our theory as an explanation for a substantial portion of the observed intercountry variation. Section 7 considers the implications of the symbiosis between stock markets and venture capital markets for efforts by other countries to expand their venture capital markets. Section 8 concludes.

\section{The venture capital industry in the United States and Germany}

In this section, we compare the venture capital industries in the United States and Germany in order to motivate the theory developed in sections 3 and 4 , in which a stock market-centered capital market (present in the United States but absent in Germany) is a precondition to a substantial venture capital industry. 
The United States has a much more fully developed venture capital market than Germany. The differences are of both size and substance. The United States has a larger number of funds and the funds themselves are larger relative to each country's economy. Substantively, United States funds are more heavily invested in early-stage ventures and high-technology industries, while German venture capital provides primarily later-stage financing in lower-technology industries.

The United States venture capital market is quite large. As of the end of 1994, 591 U.S. venture capital funds had total investments (from which the fund had not yet exited or written off) of around $\$ 34$ billion (Venture Capital Yearbook, 1995). New investment in venture capital funds in 1996 was $\$ 6.5$ billion (Figure 1). In recent years, venture capital-backed firms have raised several billion dollars annually through IPOs, including a 1996 total of $\$ 12$ billion; they form a significant portion of the total IPO market (Venture Capital Yearbook, various years through 1997; Brav \& Gompers, 1997). ${ }^{2}$ Between 1991 and 1996, there were 1,059 venture capital- backed IPOs, an average of over 175 per year (see Table 1), as well as 466 exits through acquisition of the venture-capital-backed firm.

Table 1. VC-backed IPOs, Public Acquisitions, and Private Acquisitions

Number of initial public offerings of venture-capital-backed companies and number of sales of venture-capital-backed companies, between 1984 and 1996.

\begin{tabular}{|c|c|c|c|c|}
\hline \multirow{2}{*}{$\begin{array}{c}\text { Yea } \\
\mathbf{r}\end{array}$} & \multirow{2}{*}{$\begin{array}{l}\text { VC-backed } \\
\text { IPOs }\end{array}$} & \multicolumn{3}{|c|}{ Exits via Acquisitions } \\
\hline & & $\begin{array}{c}\text { of Private } \\
\text { Com- } \\
\text { panies }\end{array}$ & $\begin{array}{c}\text { of Already } \\
\text { Public } \\
\text { Companies }\end{array}$ & Total \\
\hline 1984 & 53 & 59 & 27 & 86 \\
\hline
\end{tabular}

2 An alternate way to measure the importance of venture-capital-backed IPOs is to measure the firms' market capitalization rather than the amount of funds raised in the IPO. The 276 venture-capital-backed firms taken public in 1996 had a mean market capitalization of $\$ 209$ million and total market capitalization of $\$ 58$ billion (Venture Capital Journal, April, 1997). 


\begin{tabular}{|l|l|ccc|}
1985 & 47 & 83 & 18 & 101 \\
1986 & 98 & 90 & 30 & 120 \\
1987 & 81 & 113 & 27 & 140 \\
1988 & 36 & 106 & 29 & 135 \\
1989 & 39 & 101 & 45 & 146 \\
1990 & 42 & 76 & 33 & 109 \\
1991 & 127 & 65 & 19 & 84 \\
1992 & 160 & 90 & 4 & 94 \\
1993 & 172 & 78 & 14 & 92 \\
1994 & 143 & 99 & no data & no data \\
1995 & 183 & 98 & no data & no data \\
1996 & 276 & 94 & no data & no data \\
\hline
\end{tabular}

Source: Venture Capital Journal (various dates) (data for acquisitions of already public companies was available only through 1993)

Figure 1 shows the annual variation in the number of venture-capital-backed IPOs, as well as the amount of new capital committed to venture capital funds. Inspection of figure 1 suggests a correlation between the availability of exit through IPO (proxied by the number of venture-capital-backed IPOs) and investor willingness to invest in venture capital funds (measured by new capital commitments), with perhaps a one-year lag between a change in the number of IPOs and a resulting change in the amount of capital committed. This correlation is consistent with the theory developed below on the link between the stock market and the venture capital market.

\section{Figure 1. Venture-capital-backed IPOs and new capital commitments to venture capital funds}

Number of initial public offerings of venture-capital-backed companies (left-hand scale), and amount of new capital commitments to venture capital funds (right-hand scale), between 1978 and 1996.

[FIGURE 1 HERE]

Source: Venture Capital Journal and Venture Capital Yearbook (various dates); Economist, Mar. 29, 1997 (survey 
of Silicon Valley)

The visual impression of a correlation between venture-capital-backed IPOs and new capital commitments to venture capital funds is confirmed by a simple regression of capital contributions in year $X+1$ (as a dependent variable) against number of venture-capital-backed IPOs in year $X$. Regression 1 below shows that the number of IPOs in year $X$ correlates strongly with new capital contributions in year $X+1$. Regression 2 adds year as an additional possible explanatory variable. The correlation between number of IPOs in year $X$ and new capital commitments in the following year remains statistically significant as a predictor of new capital commitments in the following year. These regressions are not intended to fully capture the factors that affect capital commitments to venture capital funds, but do confirm the visual correlation evident from Figure 1.

\section{Table 2. Correlation Between Venture Capital Backed IPOs and New Capital Commitments to Venture Capital Funds}

Least-squares regression of capital contributed to venture capital funds ( $\$$ millions) in year $X+1$ against number of initial public offerings of venture-capital backed companies in year $X$. Based on data from 1978-1996 as shown in figure 1. t-statistics in parentheses. ${ }^{* *}\left({ }^{* *}\right)\left(^{*}\right)=$ significant at .001 (.01) (.05) level.

\begin{tabular}{|c|c|c|c|c|c|c|}
\hline & \multirow{2}{*}{$\begin{array}{c}\text { Dependent } \\
\text { Variable }\end{array}$} & \multicolumn{3}{|c|}{ Independent Variable(s) } & \multirow[t]{2}{*}{$\mathbf{R}^{2}$} & \multirow{2}{*}{$\begin{array}{c}\text { Number of } \\
\text { Observa- } \\
\text { tions }\end{array}$} \\
\hline & & Intercept & $\begin{array}{c}\text { VC-backed } \\
\text { IPOs in } \\
\text { year } X\end{array}$ & Year & & \\
\hline 1 & $\begin{array}{l}\text { Capital } \\
\text { contribution in } \\
\text { year } X+1\end{array}$ & $\begin{array}{c}1015 \\
(t=2.35)^{*}\end{array}$ & $\begin{array}{c}20.2 \\
(t=4.54)^{* * *}\end{array}$ & & .56 & 18 \\
\hline 2 & $\begin{array}{l}\text { Capital } \\
\text { contribution in } \\
\text { year } X+1\end{array}$ & $\begin{array}{l}\stackrel{\circ}{1} 137846 \\
(t=\mathrm{a} 0.93)\end{array}$ & $\begin{array}{c}15.1 \\
(t=2.17)^{*}\end{array}$ & $\begin{array}{c}70.1 \\
(t=0.94)\end{array}$ & .59 & 18 \\
\hline
\end{tabular}

United States venture capital funds obtain capital from a range of sources, but pension 
funds are the largest contributor. Pension funds have provided roughly $40 \%$ of the capital raised by venture capital funds over the last 10 years or so (Table 3). In Germany, on the other hand, banks supply the majority of venture capital commitments.

Table 3

\section{United States and Germany}

\section{Capital Raised by Venture Capital Funds By Type of Investor}

Percentage of capital raised by venture capital funds in the United States and Germany, by type of investor, for 1992-1995.

\begin{tabular}{|lcccc|}
\hline United States & $\mathbf{1 9 9 2}$ & $\mathbf{1 9 9 3}$ & $\mathbf{1 9 9 4}$ & $\mathbf{1 9 9 5}$ \\
Corporations & & & & \\
Private individuals \& families & $11 \%$ & $8 \%$ & $9 \%$ & $2 \%$ \\
Government agencies & -- & -- & -- & -- \\
Pension funds & 42 & 59 & 46 & 38 \\
Banks and insurance companies & 15 & 11 & 9 & 18 \\
Endowments and foundations & 18 & 11 & 21 & 22 \\
Other & 11 & 4 & 2 & 3 \\
\multicolumn{1}{|c}{ Total } & $\mathbf{1 0 0 \%}$ & $\mathbf{1 0 0 \%}$ & $\mathbf{1 0 0 \%}$ & $\mathbf{1 0 0 \%}$ \\
Germany & & & & \\
Corporations & $7 \%$ & $9 \%$ & $8 \%$ & $10 \%$ \\
Private individuals \& families & 6 & 7 & 8 & 5 \\
Government agencies & 4 & 6 & 7 & 8 \\
Pension funds & --- & --- & --- & 9 \\
Banks & 53 & 52 & 55 & 59 \\
Insurance companies & 10 & 12 & 12 & 6 \\
Endowments and foundations & --- & --- & --- & --- \\
Other & 17 & 14 & 10 & 2 \\
$\quad$ Total & $\mathbf{1 0 0 \%}$ & $\mathbf{1 0 0 \%}$ & $\mathbf{1 0 0 \%}$ & $\mathbf{1 0 0 \%}$ \\
\hline
\end{tabular}

Sources: European Venture Capital Association Yearbook (1995); Bundesverband Deutsche 
Kapitalbeteiligungsgesellschaften Jahrbuch [German Venture Capital Association Yearbook] (various years through 1996); Venture Capital Yearbook (various years through 1997).

Seed, startup and other early stage investments that take a company through development of a prototype and initial product shipments to customers accounted for about $37 \%$ of new capital invested by venture capital funds in 1994 (Table 4). Later-stage expansion financing represented another $45 \%$ of 1994 investments. Because venture capitalists usually stage their investments (Sahlman, 1990; Gompers 1995), most expansion financing goes to companies that received early- stage financing. Thus, the bulk of venture capital investments go to firms that receive venture capital financing very early in their life. Moreover, most investments go to technology-based companies; in $1994,68 \%$ of new investments went to these companies (Venture Economics, 1995).

Table 4

United States and Germany Venture Capital Disbursements by Stage of Financing

Percentage of capital disbursed by venture capital funds in the United States and Germany, by nature of investment, for 1992-1995.

\begin{tabular}{|lcccc|}
\hline & $\mathbf{1 9 9 2}$ & $\mathbf{1 9 9 3}$ & $\mathbf{1 9 9 4}$ & $\mathbf{1 9 9 5}$ \\
United States & & & & \\
Seed & $3 \%$ & $7 \%$ & $4 \%$ & \\
Startup & 8 & 7 & 15 & \\
Other early stage & 13 & 10 & 18 & \\
Expansion & 55 & 54 & 45 & \\
LBO/Acquisition & 7 & 6 & 6 \\
Other & 14 & 16 & 12 & \\
\multicolumn{1}{r}{ Total } & $\mathbf{1 0 0 \%}$ & $\mathbf{1 0 0 \%}$ & $\mathbf{1 0 0 \%}$ & \\
Germany & & & & \\
Seed & $1 \%$ & $1 \%$ & $2 \%$ & $2 \%$ \\
Startup & 6 & 7 & 8 & 6
\end{tabular}




\begin{tabular}{|lcccc|} 
Expansion & 45 & 66 & 54 & 65 \\
LBO/Acquisition & 24 & 25 & 36 & 18 \\
Other & 25 & --- & --- & 8 \\
\multicolumn{1}{|c|}{ Total } & $\mathbf{1 0 0 \%}$ & $\mathbf{1 0 0 \%}$ & $\mathbf{1 0 0 \%}$ & $\mathbf{1 0 0 \%}$ \\
\hline
\end{tabular}

Sources: European Venture Capital Association Yearbook (1995); Bundesverband Deutsche Kapitalbeteiligungsgesellschaften Jahrbuch [German Venture Capital Association Yearbook] (various years through 1996); Venture Capital Yearbook (various years through 1997).

Lest venture capital be dismissed as trivial in amount, and therefore not an important factor in comparing corporate governance systems, we note that mature firms which began with venture capital backing assume macroeconomic significance in the U.S. economy. They play a major, often dominant role in several important and rapidly growing sectors where the United States is recognized as a world leader, including biotechnology (for example, Genentech and Biogen); personal computers and workstations (for example, Apple, Compaq, and Sun Microsystems); many personal computer components and related devices such as hard drives and routers (for example, Seagate Technologies, Connor Peripherals, and Cisco Systems); personal computer software (for example, Lotus Development and Harvard Graphics); and semiconductors (for example, Intel and Advanced Micro Devices).

The German venture capital industry is a fraction of the size of the United States industry. Only 85 venture capital organizations existed at the end of 1994, with DM 8.3 billion ( $\$ 5.5$ billion) in cumulative capital commitments (European Venture Capital Yearbook, 1995) and annual investments of under $\$ 400$ million. Venture capital investments were $.01 \%$ of German GDP in 1994; only one-sixth of the U.S. level. This comparison understates the difference in venture capital activity between the two countries because the European definition of venture capital is broader than the American definition. These organizations received the majority of their capital from banks (55\%) and insurance companies (12\%). Pension funds are not a factor in 
the German market because German corporate and government pension obligations are largely unfunded.

The German venture capital industry also differs from the United States in its aversion both to early-stage investment (Table 4) and to investment in high-technology industries (Harrison, 1990). In 1994, only 8\% of the venture capital invested went to startup companies, and only $2 \%$ to seed financing. Technology-related investments comprised only $11 \%$ of all new investments.

In Germany, as in the United States, exit by the venture capital fund is the norm, but the form of exit differs. Exit through the stock market is largely unavailable, although a handful of German venture capital-backed firms have gone public on Britain's AIM (Alternative Investment Market). The venture capital fund's exit therefore comes principally through the company's repurchase of the venture fund's stake (a strategy not available to the rapidly growing firms that are the predominant recipients of venture capital financing in the United States), or through selling the company. Table 5 shows the exit strategies employed by German venture capital funds for 1995. Of the 12 exits through IPO, only one was in Germany; the rest were on foreign markets.

\section{Table 5}

\section{Exits by German Venture Capital Funds, 1995}

Type of exit from portfolio companies by German venture capital funds for 1995 .

\begin{tabular}{|l|c|}
\hline Exit Type & $\begin{array}{c}\text { Number of } \\
\text { Firms }\end{array}$ \\
\hline Buyback by portfolio company & 166 \\
\hline Sale of portfolio company & 74 \\
\hline Block sale of venture capital fund's stake & 8 \\
\hline Initial Public Offering & 12 \\
\hline
\end{tabular}




\begin{tabular}{|c|c|} 
(IPOs on foreign stock markets) & (11) \\
\hline Other & 4 \\
\hline Total & $\mathbf{2 6 4}$ \\
\hline
\end{tabular}

Source: Bundesverband Deutsche Kapitalbeteiligungsgesellschaften Jahrbuch [German Venture Capital Association Yearbook] (1996)

This section has only sketched the United States and German venture capital markets. But it demonstrates the pattern we seek to explain: the existence in the United States of a dynamic venture capital industry centered on early stage investments in high-technology companies and the absence of a comparable industry in Germany.

\section{The importance of exit by the venture capital fund}

The first step in understanding the link between the stock market and the venture capital market involves the importance of exit by the venture capital fund from its investments. We develop below an informal theory for why exit by venture capital providers from their successful investments is critical to the operation of the venture capital market, both for the relationship between a venture capital fund and its portfolio companies, and for the relationship between the fund and its capital providers. Florida \& Kenney (1990) argue that U.S. venture investors' refusal to act as long-term investors in portfolio companies weakens United States competitiveness. Our analysis provides an efficiency justification for exit.

The need for an exit strategy does not itself explain the distinctive properties of exit through an IPO and, therefore, the special role of an active IPO market. We develop that relationship in section 4.

\subsection{Exit from the venture capital fund - portfolio company relationship}

Venture capitalists provide more than just money to their portfolio companies. Three additional contributions loom large (Bygrave \& Timmons (1992), Barry (1994), Lerner (1995), 
Gorman \& Sahlman (1989)): management assistance to the portfolio company, analogous to that provided by a management consulting firm; intensive monitoring of performance, reflecting the incentives to monitor arising from equity ownership and the power to act using the venture capitalist's levers of control; and reputational capital, that is, the venture capitalist's ability to give the portfolio company credibility with third parties, similar to the role played by other reputational intermediaries such as investment bankers.

3.1.1. Management assistance: The typical venture capital fund is a limited partnership run by general partners who are experienced at moving companies up the development path from the startup stage and market knowledge based on other investments in the portfolio company's industry and related industries (Sahlman, 1990; Gompers \& Lerner, 1996). With this experience, the venture capitalist can assist a management-thin early-stage company in locating and recruiting the management and technical personnel it needs as its business grows, and can help the company through the predictable problems that high-technology firms face in moving from prototype development to production, marketing, and distribution. The venture capital fund's industry knowledge and experience with prior startup firms helps it locate managers for new startups (Carvalho, 1996).

3.1.2. Intensive monitoring and control: Venture capital funds have both strong incentives to monitor entrepreneurs' performance, deriving from equity ownership. They also receive strong control levers, disproportionate to the size of their equity investment. One control lever results from the staged timing of venture capital investment. The initial investment is typically insufficient to allow the portfolio company to carry out its business plan (Gompers, 1995; Sahlman, 1990). The venture capitalist will decide later whether to provide the additional funding that the portfolio company needs. The company's need for additional funds gives its 
management a performance incentive in the form of a hard constraint, analogous to the use of debt in leveraged buyouts. ${ }^{3}$

The typical contractual arrangements between a venture capital fund and a portfolio company provide other control levers. The venture capitalist typically receives convertible debt or convertible preferred stock that carries the same voting rights as if it had already been converted into common stock (Benton \& Gunderson, 1993; Gompers, 1997). ${ }^{4}$ The venture capital fund commonly receives greater board representation -- often an absolute majority of the board -- than it could elect if board representation were proportional to overall voting power. Board control lets the venture capital provider replace the entrepreneur as chief executive officer if performance lags. ${ }^{5}$ Even where the venture capitalist lacks board control, the investor rights agreement gives the venture capital provider veto power over significant operating decisions by the portfolio company.

3.1.3. Reputationalcapital: Much like an investment bank underwriting an initial public offering (Gilson \& Kraakman, 1984; Booth \& Smith, 1986), the venture capital fund acts as a reputational intermediary. Venture capital financing enhances the portfolio company's credibility with third parties whose contributions will be crucial to the company's success. Talented

3 Gompers (1995) explains the extra control rights given to the venture capital fund as a response to adverse selection problems in early-stage financing, where information asymmetries between the entrepreneur and the venture capital fund are greatest.

4 The standard contractual package for an early-stage venture capital investment consists of a convertible preferred stock purchase agreement; the portfolio company's certificate of incorporation; and an investor rights agreement. The purchase agreement, through detailed representations and warranties, documents the portfolio company's condition at the time of the venture capital investment. The certificate of incorporation sets out the voting and other rights of the venture capital fund's convertible debt or preferred stock. The investor rights agreement contains the portfolio company's ongoing obligations to the venture capital fund, including detailed negative covenants and such things as registration rights.

5 Hellman (1995a) explains why an entrepreneur would give the venture capitalist this right: to reduce the cost of capital, thereby increasing the share of the equity the entrepreneur retains. We discuss the reputation market necessary to prevent the venture capitalist from misusing this power in section 4 . 
managers are more likely to invest their human capital in a company financed by a respected venture capital fund, because the venture capitalist's participation provides a credible signal about the company's likelihood of success. Suppliers will be more willing to risk committing capacity and extending trade credit to a company with respected venture capital backers. Customers will take more seriously the company's promise of future product delivery if a venture capitalist both vouches for and monitors its management and technical progress. Moukheiber (1996) provides an account of the reputational power of Kleiner, Perkins, Caufield \& Byers, a leading venture capital fund. Later on, the venture capitalist's reputation helps to attract a high quality underwriter for an initial public offering of the portfolio company's stock (Lerner, 1994a; Meginson \& Weiss, 1991).

The venture capital fund's proffer of its reputation to third parties who have dealings with a portfolio company is credible because the fund is a repeat player, and has put its money where its mouth is by investing in the portfolio company. The fund's reputation is crucial for its own dealings with investors in its existing and future limited partnerships, with other venture capitalists in syndicating investments in portfolio companies and in negotiating with entrepreneurs concerning new portfolio investments (Sahlman, 1990; Lerner, 1994b). Consistent with a reputational analysis, Brav \& Gompers (1997) report that venture-capital-backed IPOs do not suffer the long-run underperformance reported for IPOs in general.

Like a venture capitalist's provision of financial capital, its non-financial contributions are also staged, albeit informally. A venture capitalist can choose not to make or return telephone calls to or from a portfolio company or its suppliers, customers, or prospective employees. The fund's power to withhold its management assistance and reputational capital reinforces its incentive and power to monitor. 
The management assistance, monitoring, and service as a reputational intermediary that a venture capitalist provides share a significant economy of scope with its provision of capital. This scope economy arises from a number of sources. The portfolio company must evaluate the quality of the venture capital fund's proffered management assistance and monitoring. Similarly, potential employees, suppliers, and customers must evaluate the credibility of the fund's explicit and implicit representations concerning the portfolio company's future. Combining financial and nonfinancial contributions both enhances the credibility of the information that the venture capitalist provides to third parties and bonds the venture capitalist's promise to the portfolio company to provide nonfinancial assistance. The venture capitalist will suffer financial loss if it reneges on its promise of nonfinancial support. Combining financial and nonfinancial contributions also lets investors in venture capital funds evaluate a fund's nonfinancial contributions by measuring its return on investment. Lin \& Smith (1995) also link the venture capitalist's financial and nonfinancial investments. Finally, there is the customary role of monitoring in ensuring that the portfolio company's managers do not divert to themselves some of the company's income stream.

The non-capital inputs supplied by venture capital providers have special value to early-stage companies. As the portfolio company's management gains its own experience, proves its skill, and establishes its own reputation, the relative value of the venture capital provider's management experience, monitoring, and service as a reputational intermediary declines. ${ }^{6}$ Thus, by the time the portfolio company succeeds, the venture capital provider's nonfinancial

6 Compare Rajan's (1992) analysis of the trade-off between a bank-like lender who has the ability to monitor the borrower's on-going performance and public investors who cannot monitor. As the borrower's quality improves, the returns to monitoring decrease, and the most efficient capital provider shifts from a monitoring bank-like lender to a non-monitoring investor. Diamond (1991) discusses a similar generational theory in which optimal investor type depends on a firm's stage in its life-cycle. 
contributions can be more profitably invested in a new round of early-stage companies. But because the economies of scope discussed above link financial and nonfinancial contributions, recycling the venture capitalist's nonfinancial contributions also requires the venture capitalist to exit -- to recycle its financial contribution from successful companies to early-stage companies.

\subsection{The exit and reinvestment cycle for venture capital funds and capital providers}

The efficiency of exit for the venture capitalist-portfolio company relationship complements a similar efficiency arising from the relationship between the venture capitalist and the investors in its limited partnerships. The cycle of financial commitment to early-stage firms, followed by exit from these investments, responds to three contracting problems in the venture capitalist - capital provider relationship. First, capital providers need a way to evaluate venture capitalists' skill, in order to decide to which managers to commit new funds. Second, capital providers need to evaluate the risks and returns on venture capital investments relative to other investments, in order to decide whether to invest in venture capital, and how much to invest. Third, capital providers need to be able to withdraw funds from less successful managers, or from managers whose industry-specific expertise no longer matches current investment opportunities. Yet the very specialization that explains why capital providers hire venture capitalists rather than invest directly ensures that capital providers cannot easily assess whether a venture capital fund's ongoing investments are or are likely to become successful, or how successful they are likely to be.

Exit by the venture capital manager from specific portfolio investments provides a benchmark that lets capital providers evaluate both the relative skill of venture capital managers and the profitability of venture capital relative to other investments (Gompers, 1996). At the same time, payment of the exit proceeds to capital providers lets the capital providers recycle 
funds from less successful to more successful venture capital managers.

Conventional limited partnership agreements between venture capital funds and capital providers reflect the efficiency of exit for this relationship. The limited partnership agreement typically sets a maximum term for the partnership of 7-10 years, after which the partnership must be liquidated and the proceeds distributed to the limited partners (Sahlman, 1990). During the term of the limited partnership agreement, the proceeds from investments in particular firms are distributed to limited partners as realized. Moreover, venture capital funds have strong incentives to exit from their investments, when feasible, well before the end of the partnership period. A fund's performance record, based on completed investments, is the fund's principal tool for soliciting capital providers to invest additional funds in new limited partnerships.

The explicit contract between capital providers and the venture capitalist, requiring liquidation of each limited partnership, is complemented by an implicit contract in which capital providers are expected to reinvest in future limited partnerships sponsored by successful venture capital funds. The expectation of reinvestment makes it feasible for venture capital funds to invest in developing infrastructure and expertise that will outlive the term of any one limited partnership, and could not be justified by the returns on the modest amount of capital that a venture capitalist without a track record can expect to raise. Figure 2 illustrates the explicit and implicit contracts between venture capitalists and their investors.

\section{Figure 2. Implicit and explicit contracts between venture capitalists and outside investors}

\section{[INSERT FIGURE 2 HERE]}

In sum, exit is central to the venture capital manager's accountability to capital providers. The efficiency of exit for the venture capital fund - capital provider relationship complements its 
efficiency properties for the portfolio firm - venture capital fund relationship. Taken together, they provide a strong rationale for exit from individual portfolio investments as a critical component of a viable venture capital industry.

\section{The availability of exit by IPO: Implicit contracting over future control}

The analysis in part 3 establishes the importance of an exit strategy to the venture capital market. But it does not differentiate between stock market-centered and bank-centered capital markets. A stock market makes available one special type of exit -- an initial public offering. But another exit strategy is available to venture capital funds in both bank-centered and stock-market centered capital markets: the fund can cause the portfolio company to be sold to a larger company. Indeed, even in the United States, venture capitalists frequently exit through sale of the portfolio company rather than through an IPO (Table 1). A third exit option -- leveraging the portfolio company so it can repurchase the venture capitalist's stake -- is generally not feasible for the fast-growing, capital-consuming companies that are the typical focus for venture capital investing in the U.S.

Exit through sale of the portfolio company is likely to be the most efficient form of exit in some cases. For example, innovation may be better accomplished in small firms while production and marketing may be better accomplished in large firms. In this circumstance, selling a startup company to another firm with manufacturing or marketing expertise can produce synergy gains. These gains can be partly captured by the startup firm through a higher exit price (Bygrave \& Timmons, 1992).

In other cases, an IPO may be the most efficient form of exit. The potential for an IPO to provide a higher-valued exit than sale of the company must be considered plausible, given the frequency with which this exit option is used in the United States. Viewed ex ante, venture 
capital financing of firms for which exit through IPO will (or might turn out to) maximize exit price could be a positive net present investment in a stock-market-centered capital market, but not in a bank-centered capital market. But this difference should affect investment decisions only at the margin. Thus, it cannot easily explain the dramatic differences between the venture capital industries in the United States and Germany, both in size and in type of investment.

Thus, we are only part of the way towards a theory that explains the observed link between venture capital markets and stock markets. We have shown why venture capital providers need an exit strategy. What remains to be shown is that the potential for exit through IPO, even if exit often occurs through the portfolio company's sale, is critical to the development of an active venture capital market. This part shows that the potential for exit through IPO allows the venture capital provider and the entrepreneur to enter into an implicit contract over future control of the portfolio company in a manner that is not readily duplicable in a bank-centered system.

\subsection{The contracting framework}

In a contracting framework, the relevant time to assess the influence of an IPO's availability (and therefore the importance of a stock market) on the operation of the venture capital market is when the entrepreneur and venture capital provider contract over the initial investment, not when exit actually occurs. A number of authors have modeled aspects of this contract, including the staging of the venture capitalist's funding, which vests in the venture capital provider the decision whether to continue the portfolio company's projects (Admanti \& Pfleiderer, 1994; Gompers, 1995), and the venture capital fund's purchase of a convertible security both to mitigate distributional conflicts between the entrepreneur and the venture capitalist associated with a future sale of the firm (Berglof, 1994), and to solve an adverse 
selection problem among prospective entrepreneurs (Marx, 1994; Gompers, 1997). Our informal model seeks to explain three additional characteristics of venture capital contracting: (1) the parties' ex ante joint preference that the venture capital fund exit through an IPO; (2) how the entrepreneur's preference that the fund use this exit strategy if it becomes available ex post is expressed through a self-enforcing implicit contract over future control; and (3) how this implicit contract provides the entrepreneur with incentives that are not easily duplicated if sale of the portfolio company is the only exit option. Because the incentive properties of this contract go to the heart of the entrepreneurial process, its availability in a stock-market-centered capital market links the venture capital market and the stock market and can explain the absence of vigorous venture capital in countries with bank-centered capital markets.

Our IPO exit model requires three noncontroversial assumptions: (i) the entrepreneur places substantial private value on control over the company she starts; (ii) it is not feasible for an untested entrepreneur to retain control at the time of the initial venture capital financing; and (iii) it is feasible for a successful entrepreneur to reacquire control from the venture capitalist when the venture capitalist exits. We discuss each assumption below.

A private value for control is a standard feature in venture capital models and, more generally, in models that seek to explain the incentive properties of capital structure (Holmstrom \& Tirole, 1989; Grossman \& Hart, 1988; Harris \& Raviv, 1988). Moreover, for entrepreneurs, the assumption appears to be descriptively accurate. The failure rate for startup companies is high enough $^{7}$ so that, without a large private value for control, many potential entrepreneurs would decide not to leave a secure job to start a new company. It is also apparent that ceding to

7 See Gompers (1995) (16\% of portfolio companies are liquidated or go bankrupt), Barry (1994) (one-third of venture capital investments result in losses), Sahlman (1990) (one-third of venture capital investments result in losses). Additionally, a significant percentage of would be entrepreneurs never secure venture funding at all. 
the venture capital provider the power, frequently exercised, to remove the entrepreneur from management is a significant cost to the entrepreneur (Hellman, 1995a).

Even if entrepreneurs value control highly, they cannot demand its retention at the time that they are seeking venture financing. The typical entrepreneur has not previously run a startup company. Venture capitalists rationally insist on retaining control to protect themselves against the risk that the entrepreneur won't run the firm successfully or will extract private benefits from the firm instead of maximizing its value to all investors.

The situation changes once a startup firm has succeeded. The entrepreneur has proved her management skill and provided some evidence that she can be trusted with other peoples' money. Returning control to the entrepreneur could now maximize firm value. Even if not, the value lost may be less than the entrepreneur's private value of control. The opportunity to regain control also provides an incentive, beyond mere wealth, for the entrepreneur to devote the effort needed for success. This possibility squarely raises the contracting problem that we address below: How can the venture capitalist commit, ex ante, to transfer control back to the entrepreneur, contingent on a concept as nebulous as "success"?

\subsection{The entrepreneur's incentive contract}

When the entrepreneur sells an interest in her company to a venture capital fund, the venture capitalist receives both a residual interest in the firm's value, typically in the form of convertible preferred stock or debt and significant control rights, both explicit (for example, the right to remove the chief executive officer) and implicit (for example, the right to decide whether the firm can continue in business through staged funding). In return, the company and the entrepreneur get three things. The portfolio company receives capital plus nonfinancial contributions including information, monitoring, and enhanced credibility with third parties. This 
explicit contract is illustrated in Figure 3. In addition, the entrepreneur receives an implicit incentive contract denominated in control. The structure of this incentive contract depends on the availability of an IPO exit strategy.

\section{Figure 3. Implicit and explicit contracts between venture capitalist and entrepreneur}

\section{[INSERT FIGURE 3 HERE]}

To begin with, an IPO is available to the portfolio company only when the company is successful. Indeed, the frequency with which a venture capital fund's portfolio companies go public is a central measure of the venture capitalist's success in the eyes of investors in venture capital funds (Gompers, 1996). When an IPO occurs, the entrepreneur receives two things. Like the venture capital provider, the entrepreneur gets cash to the extent that she sells some of her shares in the offering, plus increased value and liquidity for unsold shares. In addition, the entrepreneur reassumes much of the control originally ceded to the venture capitalist. The venture capitalist's percentage stake is reduced by its direct sale of shares, ${ }^{8}$ by the venture capitalist's in- kind distribution of shares to its investors (Gompers \& Lerner, 1997), and by the company's sale of new shares in the IPO to dispersed shareholders. The now-public firm also no longer depends on the venture capitalist for continuation decisions through staged funding; the public equity market is available. The greater liquidity of the venture capitalist's remaining investment after the IPO also reduces the venture capitalists' incentive to monitor (Coffee, 1991

8 Over the years 1979 through 1990, lead venture capitalists sold shares in some 27\% of IPOs of venture capital backed companies. The incidence of venture capitalist sales increased to $37 \%$ in the last three years of that period. (Lin \& Smith, 1995). 
discusses the tradeoff between monitoring and liquidity). ${ }^{9}$ The venture capitalist's need to monitor the portfolio company intensively is further reduced because some of the monitoring task will now be undertaken by stock market analysts. On average, venture capital funds reduce their holdings of a portfolio company's shares by $28 \%$ within one year after an IPO (Barry et. al, 1990). Three years after the IPO, only $12 \%$ of lead venture capitalists retain $5 \%$ or more of the portfolio company's shares (Lin \& Smith, 1995).

Finally, and most significantly, the explicit contract between the venture capital fund and the portfolio company ensures that important control rights that were initially given to the fund, including guaranteed board membership and veto power over business decisions, disappear on an initial public offering whether or not the fund sells any shares at all in the IPO. Typically, the terms of the convertible securities held by the venture capital fund require conversion into common stock at the time of the IPO (Gompers, 1997); the negative covenants contained in the investor rights agreement also terminate on an IPO (Benton \& Gunderson, 1993). In short, the venture capital fund's special control rights end at the time of an IPO, leaving the fund with only the weaker control rights attendant to substantial stock ownership. Even this control will diminish over time as the venture capital fund reduces its remaining stock position. Control becomes vested in the entrepreneur, who often retains a controlling stock interest and, even if not, retains the usual broad discretion enjoyed by chief executives of companies without a controlling shareholder.

The opportunity to acquire control through an IPO exit if the company is successful gives the entrepreneur a powerful incentive beyond the purely financial gains from the increased

9 The increased liquidity and the venture capitalist's ability to sell off its investment gradually after the initial public offering is critical because the underwriter will typically limit the amount that the venture capitalist can sell in the IPO and over the following six months lest the market draw an unfavorable inference about the portfolio company's future value from the venture capitalist's sales (Benton \& Gunderson 1993) 
value of her shares in the firm. In effect, the prospect of an IPO exit gives the entrepreneur something of a call option on control, contingent on the firm's success.

Contrast this outcome with what the entrepreneur receives when the venture capital provider exits through sale of the portfolio company to an established company. As in an IPO, the entrepreneur receives cash or the more liquid securities of a publicly traded acquirer. Control, however, passes to the acquirer, even if the entrepreneur remains in charge of day-to-day management. Thus, if an IPO exit is not available, the entrepreneur cannot be given the incentive of a call option on control exercisable in the event of success. Exit through an IPO is possible only in the presence of a stock market; its role in the contract between the venture capitalist and the entrepreneur links the venture capital market and the stock market.

\subsection{Feasibility of the implicit contract over control}

It remains to demonstrate the feasibility of the implicit incentive contract over control and its superiority to an explicit contract. We undertake these tasks in this and the next subsection. The difficulty of defining success and the potential advantages of an implicit contract are suggested by the parties' use of an implicit contract involving staged funding to handle the preIPO decision as to whether and on what terms the venture capitalist will provide additional financing.

The feasibility problem is to specify a self-enforcing implicit contract: (i) whose terms are clear; (ii) whose satisfaction by the entrepreneur is observable; and (iii) whose breach by the venture capital provider would be observable and punished by the market. Consider the following stylized implicit contract: The entrepreneur will be deemed sufficiently successful to exercise her call option on control and the venture capital provider will exit through an IPO, so long as a reputable investment banker will underwrite a firm commitment offering. The need to 
clearly specify the conditions under which the entrepreneur can exercise the call option on control is met, not by defining numerical performance standards that the portfolio company must meet, but by delegating the performance assessment to a third party. Investment bankers have an incentive to seek out (or respond to inquiries from) portfolio companies whose performance has been strong enough to allow a successful public offering. A central feature of the investment banker's role in a public offering is as an information intermediary who proffers its reputation on behalf of the portfolio company much as the venture capitalist provides credibility to the portfolio company at an earlier stage in its development. The investment banker's internal standards for companies it is willing to take public, made credible by its willingness to commit its own capital and reputation to the offering, provide a self-enforcing statement of the conditions for exercise of the entrepreneur's call option.

The second requirement, that the entrepreneur's satisfaction of the exercise conditions be observable, is met in the same way. The investment banker's offer to take the portfolio company public is directly observable by the venture capital provider and the entrepreneur and is credible because the investment banker has the right incentives to honestly evaluate a portfolio company's performance.

The final requirement, that the venture capitalist's breach of the implicit contract be observable and punishable by the market, is also met. Observability results from the character of the venture capital market. The universe of portfolio companies sufficiently successful to merit a public offering is limited, as is the number of venture capital providers. Both sides of the market are relatively concentrated, with a significant number of portfolio companies geographically concentrated and the offices of a significant percentage of U.S. venture capital providers found along a short strip of Sand Hill Road in Silicon Valley (Saxanian, 1994). Moreover, venture 
capital funds typically specialize in portfolio companies geographically proximate to the fund's office. ${ }^{10}$ While proximity facilitates monitoring, it also facilitates the emergence and maintenance of a reputation market. A claim by an entrepreneur that a venture capital provider declined to allow a portfolio company to go public when a reputable investment banker was available would quickly circulate through the community. Finally, venture capital providers are repeat players, who typically seek at regular intervals to raise funds for new limited partnerships, which must then invest in new portfolio companies, before prior limited partnerships are completed (Sahlman, 1990). In the competition to be lead venture investor in the most attractive companies, a reputation for breaching the implicit contract for control is hardly an advantage.

The viability of reputation market constraints on venture capitalist behavior is confirmed by another aspect of the overall venture capitalist-entrepreneur relationship. The venture capitalist's staged capital commitment gives the venture capitalist the option to abandon short of providing the portfolio company sufficient funds to complete its business plan. This gives the entrepreneur incentive to perform, gives the venture capitalist incentives to monitor, and reduces agency costs by shifting the continuation decision from the entrepreneur to the venture capitalist. However, this pattern, coupled with the right of first refusal with respect to future financing typically given to the venture capitalist (Sahlman, 1990), also permits the venture capitalist to act opportunistically. What can the entrepreneur do if the venture capitalist opportunistically offers to provide the second-stage financing necessary for the entrepreneur to continue at an unfair price? The entrepreneur could seek financing from other sources, but the original venture capitalist's right of first refusal presents a serious barrier: who would incur the costs of making a

10 Lerner (1994a) reports that venture capital providers located within five miles of a portfolio company are twice as likely to have a board representative than providers located more than 500 miles distant. The fact that in 1996, $40 \%$ of total venture capital disbursements were to portfolio companies in California (Venture Capital Yearbook, 1997) provides further evidence of venture capital provider concentration sufficient to support a reputation market. 
bid when potential bidders know that a bid will succeed only when a better informed party -- the original investor -- believes the price is too high? A reputation market can police this potential for opportunism. ${ }^{11}$

\subsection{Superiority of the implicit contract over control}

An explicit contract that specifies the operating performance necessary to entitle the entrepreneur to reacquire control is a difficult undertaking. Creating a state-contingent contract that specifies the control consequences of the full range of possible states of the world over the four- to ten-year average term of a venture investment, without creating perverse incentives, is a severe challenge both to the parties' predictive powers and their drafting capabilities. It is in precisely these circumstances that an implicit contract is likely to have a comparative advantage over an explicit contract.

Moreover, the venture capitalist will be willing to cede control only at the time of exit, not before. Yet a mechanical formula cannot ensure that a reputable underwriter will be willing to take the portfolio company public. In addition, the venture capitalist must actively cooperate for an IPO to succeed. At the same time, the venture capitalist cannot unduly "puff" the portfolio company's prospects, because the capital markets will punish this behavior through reduced marketability of IPOs of other portfolio companies. Thus, a supposedly explicit contract, defining when the entrepreneur and the venture capital fund have the right to take the portfolio company public, cannot easily be enforced. Such a contract would be substantially implicit in fact, even if explicit in form. Thus, it isn't surprising that entrepreneurs and venture capitalists, for the most part, don't seek to contract explicitly over control.

Finally, the implicit/explicit dichotomy presented above oversimplifies the real world. In

11 Admati \& Pfleiderer (1994), who model the shift of the continuation decision to the venture capitalist, do not address this problem. 
fact, some elements of the contract over control are explicit, while others are left implicit. For example, cessation of the venture capital fund's special control rights at the time of an IPO is explicitly required, while the timing of the triggering event -- the IPO -- is left implicit. Conversion of the venture capitalist's convertible securities into common stock special rights is sometimes explicitly required if the portfolio company achieves defined financial milestones, even without an IPO (Benton \& Gunderson, 1993; Gompers, 1997). Also, consistent with the greater importance of control earlier in a firm's life, the venture capitalist's explicit control rights are generally stronger, the earlier the stage of the investment (Gompers, 1997).

\subsection{Consistency with empirical evidence}

In our model, successful entrepreneurs often prefer exit by IPO, and have the implicit contractual right to demand this form of exit not only when it maximizes firm value compared to the alternative of sale of the firm, but also when the entrepreneur's private value of control outweighs the entrepreneur's loss in share value. Our model predicts that the venture capitalist's successful exits will take place disproportionately through IPO. If so, IPO exits will be more profitable than exits through sale of the portfolio company, by more than can plausibly be explained by the different values available through these different forms of exit.

This prediction is confirmed. Gompers (1995) reports that venture capital funds earn an average $60 \%$ annual return on investment in IPO exits, compared to $15 \%$ in acquisition exits; see also Petty, Bygrave \& Shulman (1994); Sagari \& Guidotti (1993). MacIntosh (1996) reports that IPO exits are more profitable in Canada as well. It is not plausible that these large differences could arise if the venture capitalist chose in each case the exit that maximized return on investment.

\section{Evidence from other countries}


We have developed an informal theory in which the success of early stage venture capital financing of high-growth, often high-technology firms, is linked to the availability of exit through an initial public offering. The weak form of the theory is that IPO exit is preferred by entrepreneurs. This preference leads to an implicit contract over control between the entrepreneur and the venture capitalist, in which the entrepreneur's success is rewarded by giving the entrepreneur the option to reacquire control through an IPO exit. This theory is consistent with the evidence discussed in part 2 of a correlation between frequency of IPO exit and amount of new capital contributed to venture capital funds, and the evidence in section 4.5 that successful exits occur disproportionately through IPO.

The strong form of our theory is that the entrepreneur's preference for control is strong enough to significantly impair the development of a venture capital market in countries where exit by acquisition is the only viable option. This section offers an informal test of the strong form of our theory: Does the theory predict the observed success of venture capital in different countries with different types of capital markets? We provide data on Germany and the United States in part 2; we survey several other countries below.

\subsection{Japan}

We have only limited quantitative data on the size of the venture capital industry in Japan. However, the quantitative and qualitative data that we have (primarily from Milhaupt, 1997) is consistent with our theory: Japan, with its bank-centered capital market, has relatively little venture capital. In 1995, there were only 121 venture capital funds, of which more than half were affiliated with banks and run by the parent bank's employees. The employees of bank-affiliated funds commonly rotate through jobs in the bank's venture capital affiliate and then return to the parent bank. Thus, they are unlikely to develop the special skills needed to evaluate 
high-technology investments. Another 25 Japanese venture capital funds were run by securities firms or insurance companies.

Unlike American venture capital funds, which primarily provide equity financing, Japanese funds, perhaps reflecting their parentage, provide funds mostly through loans. Where American venture capital funds concentrate on high-tech businesses, and are the principal capital source for many startup high-tech firms, Japanese venture capital firms rarely invest in high-technology firms. Instead, they concentrate on manufacturing and services, including such mundane investments as small shops and restaurants. As of 1995, Japanese venture capital funds owned more than $10 \%$ of the stock of only one biotechnology company, two new materials firms, and 12 electronics firms.

\subsection{Great Britain and Other European Countries}

The similarity between Germany and Japan in the weakness of their venture capital industries strengthens the empirical support for the claim that bank-centered capital markets do not develop a strong venture capital industry. The converse claim is that stock-market centered capital markets can develop a strong venture capital industry. In particular, our theory predicts that Great Britain, with its active stock market, should have comparatively strong venture capital industries. This prediction is also supported by the evidence. British GDP is only about two-thirds of Germany's, yet its venture capital industry is almost five times larger, measured by cumulative capital committed (Economist, 1996); new capital commitments are comparable to the United States as a percentage of GDP. Ireland, with its easy access to the London stock market, also has relatively high venture capital as a percentage of GDP. Britain and Ireland are the clear European leaders in venture capital, with everyone else far behind.

Table 6 shows new funds raised by venture capital funds in 1993 and 1994 as a 
percentage of GDP. Great Britain's lead over everyone else would be greater still if the data were classified by the venture capital fund's home country, because British-based venture capital funds invest substantial amounts through affiliates in other European countries.

Table 6

New Capital Committed to Venture Capital Funds, 1993-1994

(percent of GDP)

New capital commitments to venture capital funds, as percent of national GNP, for various countries between 1993 and 1994.

\begin{tabular}{|c|c|c|c|}
\hline \multirow[t]{2}{*}{ Country } & \multicolumn{2}{|c|}{ Year } & \multirow{2}{*}{$\begin{array}{l}\text { Average: } \\
\text { 1993-1994 }\end{array}$} \\
\hline & 1993 & 1994 & \\
\hline United States & $.03 \%$ & $.06 \%$ & $.05 \%$ \\
\hline Great Britain & .09 & .27 & .18 \\
\hline Great Britain & .09 & .27 & .18 \\
\hline France & .06 & .07 & .06 \\
\hline Italy & .02 & .02 & .02 \\
\hline Germany & .01 & .01 & .01 \\
\hline Netherlands & .04 & .07 & .05 \\
\hline Spain & .03 & .01 & .02 \\
\hline Sweden & .06 & .06 & .06 \\
\hline Ireland & .04 & .25 & .15 \\
\hline Portugal & .06 & .07 & .06 \\
\hline Belgium & .04 & .03 & .04 \\
\hline Denmark & .01 & .08 & .04 \\
\hline Switzerland & .03 & .02 & .03 \\
\hline Norway & .05 & .03 & .04 \\
\hline Finland & .01 & .04 & .02 \\
\hline Iceland & .06 & 0 & .03 \\
\hline Austria & 0 & 0 & 0 \\
\hline
\end{tabular}

Source: European Venture Capital Association, 1995. 
These data understate the relative size of the U.S. venture capital industry. European venture capital firms are less specialized than their American counterparts and are often affiliated with commercial banks. The European Venture Capital Association defines "venture capital" to include leveraged buyouts and buyins, and replacement of a firm's existing financing. In contrast, leveraged buyout firms in the United States are a distinct industry from venture capital firms; venture capital is also distinct from non-venture private equity financing. Non-venture uses of funds by European "venture capital" firms are substantial. For example, in Great Britain, $47 \%$ of capital commitments in 1994 went to buyins and buyouts, and only $8 \%$ to early stage financing. In France, $40 \%$ of venture capital comes from banks, and in 1994, 51\% of funds committed went to buyouts, buyins, and replacement financing, while only $9 \%$ went to early stage financing.

\subsection{Canada}

Our evidence on Canada is drawn primarily from the recent survey by MacIntosh (1996).

Canada has a relatively open IPO market -- both domestic IPOs and access to the U.S. IPO market. Thus, our theory predicts that Canada should have a relatively active venture capital industry. The Canadian data are difficult to interpret because of heavy government intervention in the venture capital industry. Labor Sponsored Venture Capital Corporations (LSVCCs), which must be formed by a labor union, receive substantial tax benefits. As a result, they dominate the Canadian venture capital industry. These funds tend to invest more conservatively than other venture capital funds. The largest single LSVCC fund, the Solidarite fund, is owned by the government of Quebec.

Still, there is substantial evidence that Canadian venture capital funds, especially private funds, play a large role in early-stage financing of high-technology Canadian firms. In 1994, private independent funds had $\mathrm{C} \$ 1.8$ billion under management, and all Canadian venture capital 
firms had C $\$ 4.5$ billion under management. The latter figure is comparable to the United States after adjusting for the size of the economy. Moreover, $25 \%$ of new capital went to early-stage financing -- a figure similar to that for the United States, and much higher than for European and Japanese venture capital firms. The percentage of early-stage investments is likely higher than this for non-LSVCC funds. In Canada, as in the United States, IPO exit is common and the highest-return exits are through IPOs.

\subsection{Israel}

Israel offers an interesting case study of how an existing venture capital industry can adapt when the option of a domestic IPO is taken away through regulation. The Israeli economy has grown rapidly during the 1990 s, partly in response to deregulation of a formerly heavily government-controlled economy. High-technology startups, often financed by venture capital funds, have been an important element in this growth (Gourlay, 1996). Multiple elements have contributed to the Israeli high-technology and venture capital industries, including government guarantees against large losses by publicly traded venture capital funds in the form of a put option on the fund's shares, government creation of incubator facilities for startup firms, and a substantial influx in the early 1990s of immigrant scientists from Russia.

In the early 1990s, Israeli high-technology firms often went public on the Tel Aviv Stock Exchange at a very early stage. After a stock price crash in early 1994, the Tel Aviv Stock Exchange adopted listing rules that limited IPOs by early-stage companies. Israeli venture capital funds have nonetheless continued to flourish by shifting their IPOs from the Tel Aviv Stock Exchange to the NASDAQ market. Giza Group (1996) reports the results of 16 IPOs of venture capital-backed Israeli companies from 1993 through early 1996, of which 14 were on NASDAQ, one on the British "AIM" small-firm market, and one on the Tel Aviv Stock Exchange. As of 
March 31, 1997, 62 Israeli companies had listed securities on NASDAQ, including 22 in 1996 alone; most were high-tech companies. The cumulative total exceeds any other country's except Canada's, and far exceeds any other country's relative to GDP.

\section{Alternative explanations for intercountry variations in venture capital}

We have developed in this paper an informal theory, based on the stock market's role in providing contracting options not available in a bank-centered capital market, that may partially explain cross-country variations in venture capital. In this section, we evaluate briefly several alternative explanations for the different levels of venture capital financing in stock market-centered and bank-centered capital markets. We first consider a claim of functional irrelevance: institutional differences between stock market-centered and bank-centered systems do not affect economic outcomes because bank-centered systems have developed functionally equivalent means for financing early-stage entrepreneurial activities. We then turn to explanations that acknowledge differences between countries in their ability to provide financing for high-technology ventures, but assign causation differently than we do.

While our analysis here is only suggestive, differential performance between the United States and Germany in industries where venture capital plays a significant role in the U.S. suggests that Germany has not yet developed a functional substitute for venture capital. Alternative explanations may account for some of this functional difference, but none appears able to fully displace the account of cross-national differences offered here.

\subsection{Institutional but not functional differences}

Different methods of organizing capital markets do not necessarily dictate corresponding functional or performance differences. For example, empirical research by Kaplan (1994a, 1994b) and Kaplan \& Minton (1994) suggests that Japanese and German companies change top 
management in response to poor earnings and stock price performance about as often and as quickly as United States companies, despite the three countries' quite different corporate governance institutions. The similar outcomes could reflect the impact of selection on path-dependent corporate governance systems. That three leading industrial economies change senior management under roughly the same circumstances may reflect a selection bias. By limiting the sample to these successful systems, we observe only systems that, within the constraints established by their particular institutions, have solved reasonably well the central corporate governance problem of replacing poorly performing managers (Gilson, 1996; Kaplan \& Ramseyer, 1996).

The same functional equivalence argument can be made with respect to differences in how successful economies finance entrepreneurial activities. If other financing methods, such as bank financing of startup companies or internalization of the entrepreneurial process by large companies, yields the same performance as the United States' venture capital market, then the institutional differences are historically interesting but not functionally significant.

The empirical evidence needed to assess the functional equivalence argument for venture-capital financed industries is not available, but anecdotal evidence makes us skeptical about functional equivalence. The United States has become a world leader in precisely those industries, notably biotechnology and computer-related high technology, in which the venture capital market figures centrally (Powell, 1996). Moreover, in both Europe and the United States, large pharmaceutical companies are responding to biotechnology entrepreneurship not by funding the entrepreneurs directly, but instead by providing later-stage financing and partnering arrangements to entrepreneurial companies, mostly U.S.-based and originally financed through U.S. venture capital. (Powell, 1996; Hellman, 1995b; Lerner \& Merges, 1997). The result is not 
functional equivalence but specialization: Different activities are allocated to different countries on the basis of differences in their venture capital markets.

\subsection{The role of pension fund financing of venture capital}

In both Japan and Germany, pension funds do not invest in venture capital. In Germany, corporate pension obligations are typically unfunded, so large private pension plans do not exist. Japan has moderate sized corporate pension plans, but these plans are barred by law from investing in venture capital (Milhaupt, 1997). In the United States, in contrast, the Department of Labor in 1979 explicitly sanctioned pension fund investment in venture capital. As shown in Table 3, pension plans now provide over $40 \%$ of total investment in U.S. venture capital funds.

Differences in pension fund size and regulation can explain part, but in our judgment only part, of the cross-national differences in the size of the venture capital industry. Funded pension obligations, as in the United States, as opposed to unfunded pension obligations in Germany, dictate only who makes employee pension investments, not the investments themselves. A company with an unfunded pension plan, in effect, incurs an unsecured debt -- its promise to pay pensions when workers retire. The company can invest the funds thus made available in any way it chooses, including in venture capital. German firms could also voluntarily fund their pension obligations, as many American firms did even before ERISA established minimum funding requirements in 1973. The pension plan could then invest in venture capital, if it so chose.

In the U.S., the unclear legality of pension fund investments in venture capital between 1973 and 1979 sterilized this pool of investable funds. Not surprisingly, the 1979 regulatory change resulted in a flow of funds into the previously restricted area. German firms have never been subject to an investment restriction similar to 1973-1979 U.S. regulation. 
More generally, money is the ultimate fungible commodity, and venture capital commitments are a tiny fraction of total business investment -- in the U.S., around $\$ 5$ billion annually compared to gross investment of over $\$ 1$ trillion. If there were attractive profits to be made from venture capital investing, it seems likely that funds would be available from other sources, even if not from pension plans. After all, the Germans and the Japanese save more than Americans as a percentage of GDP, merely in different forms.

\subsection{Differences in labor market regulation}

Germany and a number of other Western European countries impose substantial restrictions on layoffs, especially severance payment obligations. These rules impose costs on startup businesses and thus could discourage their formation. Variations in labor market restrictions correlate with observed national variations in venture capital. Germany has strong layoff protections and little venture capital. Japan has few formal restrictions on layoffs, but the common practice by large companies of hiring only recent college graduates and promising them lifetime employment reduces labor market mobility (Gilson \& Roe, 1997). In contrast, the United States and Britain have more flexible labor markets and more active venture capital markets.

Labor market regulation and practices could well affect the vitality of venture capital. For example, Gilson (1997) argues that weak enforcement of covenants not to compete is a factor in the strength of venture capital in California; Hyde (1997) argues that the concentration of venture-capital-backed firms in Silicon Valley both supports and depends on what he calls "high velocity" labor markets. But labor market regulation, as a partial explanation for the vitality of venture capital markets, seems unlikely to fully displace our explanation, based on differences in capital markets. 
Consider Germany as an example. Severance obligations build over time; they are much less burdensome for a startup firm that fails after a few years of operation than for a mature firm that closes a plant that has operated for decades. Moreover, unpaid severance obligations are of little significance if a firm goes bankrupt -- they merely expand the pool of unsecured claims on the firm's assets.

Moreover, labor market restrictions do not map perfectly onto national patterns in venture capital activity. Canada has moderately strong labor market restrictions; Ireland and Israel have strong restrictions comparable to West Germany's. Yet these countries also have strong venture capital. This pattern is consistent with their access to stock markets: the London market for Ireland; the U.S. market for Israel; and U.S. and domestic stock markets for Canada.

\subsection{Cultural differences in entrepreneurship}

A final explanation is cultural. Germans and Japanese could be less entrepreneurial and less willing to risk failure than Americans, leading to lesser demand for venture capital services (Milhaupt, 1997, discusses Japanese culture). Cultural explanations for different patterns of economic activity are hard to evaluate. They can be partly tautological. In economically successful countries like Germany and Japan, the forces of economic selection will cause culture and economic institutions to become mutually supportive. Because both are endogenously determined, observing that cultural institutions support existing economic patterns tells us nothing about causation. For present purposes, the more interesting issue is not a static inquiry into the current equilibrium of culture and economic institutions, but a dynamic one: how can culture and institutions change in response to exogenous changes in the economic environment

(North, 1990, 1994). We briefly consider this issue from an instrumental perspective in section 7. 
However, there is some reason for skepticism about claims of large cultural differences in willingness to take risks. People in all countries found large numbers of businesses, most of which fail. The empirical regularity to be explained is not why the Germans and Japanese do not start risky new businesses, but why they do not start many high-technology businesses, with few tangible assets on which a bank can rely for partial return of its investment. The success of immigrant entrepreneurs in countries with strong venture capital (for example, Russian immigrants in Israel and Asian immigrants in the United States) suggests that entrepreneurs will emerge if the institutional infrastructure needed to support them is available. After all, Russia and India are also not known for their cultural support of entrepreneurship. Moreover, efforts to find large cross-cultural differences in entrepreneurship between the U.S. and Russia at the close of the Communist period have failed, even though these two countries ought to exhibit much larger differences than the United States, Germany, and Japan (Shiller, Boycko \& Korobov, 1991, 1992).

\section{Implications for venture capital in bank-centered capital markets}

Exploring the implications of the link between venture capital markets and stock markets is more complicated than the simple admonition that bank-centered capital markets should create a stock market. That straightforward approach has been tried before and failed. For example, France and Germany created special stock exchange segments for newer, smaller companies during the 1980s that, by the mid-1990s, had been shuttered or marginalized (Rasch, 1994). Nonetheless, the financial press still stresses the absence of a venture capital market as being at the root of the European high technology sector's poor performance, particularly with respect to Germany (e.g., Fisher, 1996a, 1996b), and three efforts are underway to try again to create stock markets that cater to small high-technology companies. The Alternative Investment Market of 
the London Stock Exchange began trading in June 1995 and now lists over 200 firms (Price, 1996). Euro NM, a consortium of the French Le Nouveau Marche', which began trading in February, 1996, the German Neur Market, and the Belgian New Market, is scheduled to begin full operation in 1997. Finally, EASDAQ, an exchange explicitly patterned after the U.S. NASDAQ and of which the NASD is a part owner, opened on September 30, 1996 (Pickles, 1996). This flurry of stock market creation, taken with the explicit goal of enhancing the European venture capital market, suggests that there may be value in exploring the normative implications of the stock market-venture capital market link.

We begin our analysis of this link by stressing the path dependency of national capital markets. It is not merely a stock market that is missing in bank-centered systems. The secondary institutions that have developed in bank-centered systems, including the banks' conservative approach to lending and investing, and social and financial incentives that less richly reward entrepreneurial zeal and more severely penalize failure (See Harrison, 1990 (Germany); Milhaupt, 1997 (Japan)), are less conducive to entrepreneurial activity than the secondary institutions of stock market-centered capital markets. More critically, experienced venture capitalists, able to assess the prospects of new venture and to provide the nonfinancial contributions that venture capitalists supply in the United States are absent, as are investment bankers experienced in taking early-stage companies public. Neither institution will develop quickly. A strong venture capital market thus reflects an equilibrium of a number of interdependent factors, only one of which is the presence of a stock market.

For example, Germany today faces a chicken and egg problem: a venture capital market requires a stock market, but a stock market requires a supply of entrepreneurs and deals which, in turn, require a venture capital market. In addition, German entrepreneurs who care about 
future control of their company must trust venture capitalists to return control to them some years hence and must further trust that the stock market window will be open when they are ready to go public. The institutional design issue is how to simultaneously create both a set of mutually dependent institutions and the trust that these institutions will work as expected when called upon.

In such a path-dependent equilibrium, the cost of change is the guard rail that keeps us on the path. We remain in an equilibrium less efficient than would be possible without the transaction costs of creating the institutions needed to support alternatives (Kohn, 1995). While we do not aspire to offer a solution here, our analysis suggests an approach to creating the conditions conducive to a vigorous venture capital market: avoid the problem of creating multiple new institutions by piggybacking on another country's institutions. If this is successful, a profit opportunity and corresponding potential for the development of local institutions will be created.

Most obviously, in the increasingly global capital market, the German venture capital market could follow Israel's lead in relying on the United States stock market and its supporting infrastructure. A German company that maintains accounting records in a fashion consistent with U.S. standards -- arguably much less of a burden when done from the beginning than if implemented by a conversion, as when Daimler-Benz listed its shares on the New York Stock Exchange -- confronts no regulatory barrier to listing on NASDAQ, the exchange most suitable to venture-capital-backed IPOs. At present, over 100 European companies, including one German company, list their shares on NASDAQ. Many of these listings represent the initial public offering of the company's stock. With NASDAQ comes its institutional infrastructure. For example, both Hambrecht \& Quist and Robertson, Stephens \& Co., leading investment bankers for venture-capital-backed IPOs in the United States, are opening European offices and holding 
conferences to introduce American venture capital funds to European entrepreneurs (Lavin, 1996). Silicon Valley law firms are also actively recruiting European IPO candidates.

The availability of this institutional infrastructure, without the costs of establishing it from scratch, can shorten the shadow of the past and, in the medium term, induce the development of competing local institutions. For example, in the near term, foreign venture capitalists will likely find it profitable to hire and train locals to help them find profitable investment opportunities. In the medium term, some of these people, once trained, will form their own firms and compete with their former employers.

\section{Conclusion}

In this paper. we have examined one of the path-dependent consequences of the difference between stock market-centered and bank-centered capital markets: the link between an active stock market and a strong venture capital market. We have shown that economies of scope among financial and nonfinancial contributions by venture capital providers, plus venture capital investors' need for a quantitative measure of venture capital funds' skill, can explain the importance of an exit strategy. Moreover, the potential for exit through an IPO, possible in a stock-market-centered capital market, allows the venture capitalist and the entrepreneur to contract implicitly over control, in a manner that is not easily duplicable in a bank-centered capital market. Finally, we have suggested that the best strategy for overcoming path dependent barriers to a venture capital market in bank-centered systems is to piggyback on the institutional infrastructure of stock-market-centered systems.

Our model seeks to explain the importance of a possible IPO exit for a high-growth firm financed by a venture capital fund, for which exit by the fund is desirable at a stage in the firm's life when it is still consuming rather than generating capital. For a mature, cash-generating firm, 
another exit strategy that preserves the entrepreneur's control is possible: the firm itself can buy back the venture capital fund's stake, perhaps by borrowing the needed funds. This strategy permits a somewhat different implicit contract over control between the fund and an entrepreneur: if the firm is successful enough to buy out the fund, the fund will acquiesce in this strategy even if this form of exit does not maximize the fund's return on an individual investment. In the United States, this form of exit is associated not with venture capital funds but with "leveraged buyout" funds. In Europe, which has a less clear distinction between venture capital and leveraged buyouts, this form of exit is common when venture capital funds invest in management buyouts of mature firms. We plan to explore in future work the possible extension of our model to the leveraged buyout industry. 


\section{References}

Admati, A., Pfleiderer, P., 1994. Robust financial contracting and the role of venture capitalists. Journal of Finance 49, 371-402.

Aoki, M., 1994. Monitoring characteristics of the main bank system: An analytical and developmental view. In Aoki, M., Patrick, H., (Eds), The Japanese main bank system: Its relevance for developing and transforming economies. Oxford University Press, Oxford.

Barry, C., 1994. New directions in venture capital research. Journal of Financial Management 23, 3-15.

Barry, C., Muscarella, C., Peavy J., III, Vetsuypens, M., 1990. The role of venture capitalists in the creation of a public company. Journal of Financial Economics 27, 447-471.

Benton, L., Gunderson, R.,Jr., 1993. Portfolio company investments: Hi-tech corporation, Venture Capital and Public Offering Negotiation. In Halloran, M., Benton, L., Gunderson, R., Jr., Kearney, K., del Calvo, J., (Eds.) Law \& Business, Inc. Harcourt Brace Jovanovich, New York.

Bergloff, E., 1994. A control theory of venture capital finance. Journal of Law, Economics \& Organization 10, 247-267.

Black, B., 1990. Shareholder passivity reexamined. Michigan Law Review 89, 520-608.

Booth, J., Smith, R., 1986. Capital raising, underwriting and the certification hypothesis. Journal of Financial Economics 15, 261-281.

Brav, A., Gompers, P., 1997. Myth or reality? The long-run underperformance of initial public offerings: Evidence from venture and nonventure capital-backed companies, Journal of Finance, forthcoming.

Bundesverband Deutsche Kapitalbeteiligungsgesellschaften (BVK) Jahrbuch [German Venture Capital Association Yearbook], various years through 1996 (BVK, Berlin, Germany).

Bygrave, W., Timmons, J., 1992. Venture capital at the crossroads. Harvard Business School Press, Cambridge, MA.

Carvalho, A., 1996. Venture capital as a network for human resources allocation. Unpublished working paper. University of Illinois.

Coffee, J., 1991. Liquidity versus control: The institutional investor as corporate monitor. Columbia Law Review 91, 1277-1368.

Diamond, D., 1991. Monitoring and reputation: The choice between bank loans and directly placed debt. Journal of Political Economy 99, 689-721.

Economist, 1996. Going for the golden egg. Sept. 28, 1996, at 89.

Edwards, J., Klaus F., 1994. Banks, finance and investment in Germany. Cambridge University Press, Cambridge.

European Venture Capital Association. 1995. EVCA Yearbook 1995. Ernst \& Young, London, England.

Fisher, A., 1996a. A venture across the pond. Financial Times, July 24, 1996, 12.

Fisher, A., 1996b. Germans urged to take a risk for jobs. Financial Times, July 16, 1996, 2.

Florida, R., Martin, K., 1990. The breakthrough illusion: Corporate America's failure to move from innovation to mass production. BasicBooks, New York.

Gilson, R., Kraakman, R., 1984. The mechanisms of market efficiency. Virginia Law Review 70, 549-644.

Gilson, R., Roe, M., 1997. Lifetime employment: Labor peace and the evolution of Japanese corporate governance. Unpublished working paper. Columbia Law School. 
Gilson, R., 1996. Corporate governance and economic efficiency. Washington University Law Quarterly 74, 327-345.

Gilson, R., 1997. The legal infrastructure of high-technology industrial districts: Silicon Valley and covenants not to compete. Unpublished working paper. Stanford Law School.

Giza Group, 1996. Survey of venture capital and investment funds in Israel: August 1996 Update. Giza Group, Tel Aviv, Israel.

Gompers, P., 1997. An examination of convertible securities in venture capital. Journal of Law and Economics, forthcoming.

Gompers, P., 1996. Grandstanding in the venture capital industry. Journal of Financial Economics 42, 133-156.

Gompers, P., 1995. Optimal investment, monitoring, and the staging of venture capital. Journal of Financial Economics 50, 1461-1489.

Gompers, P., Lerner, J., 1996. The use of covenants: An empirical analysis of venture partnership agreements. Journal of Law and Economics 39, 463-498.

Gompers, P., Lerner, J., 1997. Venture capital distributions: Short-run and long-run reactions. Unpublished working paper. Harvard Business School.

Gorman, M., Sahlman, W., 1989. What do venture capitalists do? Journal of Business Venturing 4, $231-248$.

Gourlay, R., 1996. The development of a venture capital industry lies behind the economic success of a new breed of high-tech Israeli company. Financial Times, April 30, 1996, 14.

Grossman, S., Hart, O., 1988. One share-one vote and the market for corporate control. Journal of Financial Economics 20, 175-202.

Harris, M., Raviv, A., 1988. Corporate governance: voting rights and majority rules. Journal of Financial Economics 20, 203-235.

Harrison, E., 1990. The West German venture capital market. Peter Lang, Frankfurt am Main, Frankfurt, Germany.

Hellman, T., 1995a. The allocation of control rights in venture capital contracts. Research Paper No. 1362. Stanford Business School, Stanford.

Hellman, T., 1995b. Competition and cooperation between entrepreneurial an established companies: The viability of corporate venture investments. Unpublished working paper. Stanford Business School, Stanford.

Hyde, A., 1997. High-velocity labor markets. Unpublished working paper. Rutgers Law School.

Hoshi, T., 1993. Evolution of the main bank system in Japan. Unpublished working paper. University of California at San Diego.

Jensen, M., 1989. The eclipse of the public corporation. Harvard Business Review. Sept.-Oct., 61-73.

Kaplan, S., 1994. Top executive rewards and firm performance: a comparison of Japan and the United States. Journal of Political Economy 102, 510-546.

Kaplan, S., 1994. Top executives, turnover, and firm performance in Germany. Journal of Law, Economics and Organization 10, 142-159.

Kaplan, S., Minton, B., 1994. Appointments of outsiders to Japanese boards: determinants and implications for managers. Journal of Financial Economics 36, 225-258.

Kaplan, S., Ramseyer, J., 1996. Those Japanese firms with their disdain for shareholders: another fable for the 
academy. Washington University Law Quarterly 74, 403-418.

Kohn, M., 1995. Economics as a theory of exchange. Unpublished working paper. Dartmouth College Department of Economics, Dartmouth, NH.

Lavin, D., 1996. The sky's the limit. Convergence 2, 8.

Lerner, J., 1995. Venture capitalists and the oversight of private firms. Journal of Finance 50, 301-318.

Lerner, J., 1994a. The syndication of venture capital investments. Financial Management 23, 16-27.

Lerner, J., 1994b. Venture capitalists and the decision to go public. Journal of Financial Economics 35, 293-316.

Lerner, J., Merges, R., 1997. The control of strategic alliance: an empirical analysis of biotechnology collaborations. Working paper No. 6014. National Bureau of Economic Research.

Lin, T., Smith, R., 1995. Insider reputation and selling decisions: the unwinding of venture capital investments during equity IPOs. Unpublished working paper. Claremont Graduate School.

MacIntosh, J., 1996. Venture capital exits in Canada and the U.S. Unpublished working paper. University of Toronto Faculty of Law.

Marx, L., 1994. Negotiation of venture capital contracts. Unpublished working paper. University of Rochester.

Megginson, W., and Weiss, K., 1991. Venture capital certification in initial public offerings. Journal of Finance $46,879-903$.

Milhaupt, C., 1997. The market for innovation in the United States and Japan: Venture capital and the comparative corporate governance debate. Northwestern University Law Review 91, 865-898.

Moukheiber, Z., March 25, 1996, Kleiner's web. Forbes, 40-42.

North, D., 1994. Economic performance through time. American Economic Review, 84, 359-368.

North, D., 1990. Institutions, institutional change, and economic performance. Cambridge University Press, Cambridge, England.

Petty, W., Bygrave, W., Shulman, J., 1994. Harvesting the entrepreneurial venture: A time for creating value. Journal of Applied Corporate Finance. Spring, 48-58.

Pickles, C., 1996. One answer to Europe's capital needs. Wall Street Journal, Europe, October 23, 1996.

Porter, M., 1992. Capital disadvantages: America's failing investment system. Harvard Business Review, Sept.Oct, 65-82.

Powell, W., 1996. Inter-organizational collaboration in the biotechnology industry. Journal of Institutional and Theoretical Economics 152, 197-215.

Price, C., 1996. EASDAQ pins hopes on NASDAQ. Financial Times, Sept. 30, 1996, 23.

Rajan, R., 1992. Insiders and outsiders: the choice between informed and arm's length debt. Journal of Finance 47, 1367-1400.

Rasch, S., 1994. Special stock market segments for small company shares in Europe -- what went wrong? Discussion Paper No. 93-13. Center for European Economic Research.

Roe, M., 1994. Strong managers, weak owners: The political roots of American corporate finance. Princeton University Press, Princeton.

Sahlman, W., 1990. The structure and governance of venture capital organizations. Journal of Financial Economics $27,473-522$. 
Sagari, S., and Guidotti, G., 1993. Venture capital: The lessons from the developing world for the developing world, Financial Markets. Instruments and Investments 1, 31-42.

Saxanian, A., 1994. Regional advantage: Culture and competition in silicon valley and route 128. Harvard University Press, Cambridge MA.

Shiller, R., Boycko, M., Korobov, V., 1991. Popular attitudes toward free markets: The Soviet Union and the United States compared. American Economic Review 81, 385-400.

Shiller, R., Boycko, M., Korobov, V., 1992. Hunting for Homo Sovieticus: Situational versus attitudinal factors in economic behavior. Brookings Papers on Economic Activity, 127-181.

Venture Capital Yearbook, various years through 1997. Venture Economics Publishing, New York. 
Figure 1

Venture Capital-backed IPOs and New Venture

Capital Commitments

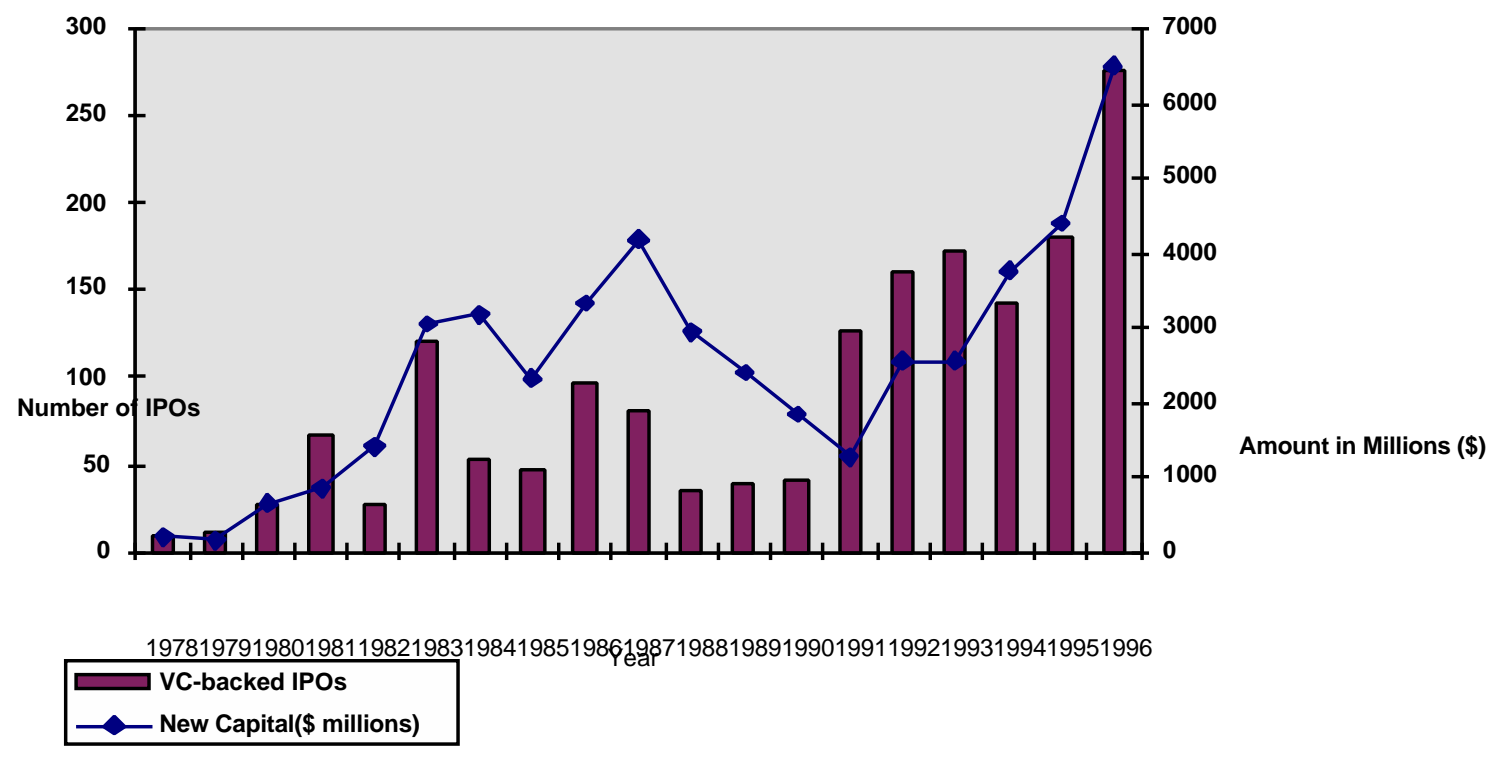


Figure 2

Implicit and Explicit Contracts

Between Venture Capitalists and Outside Investors
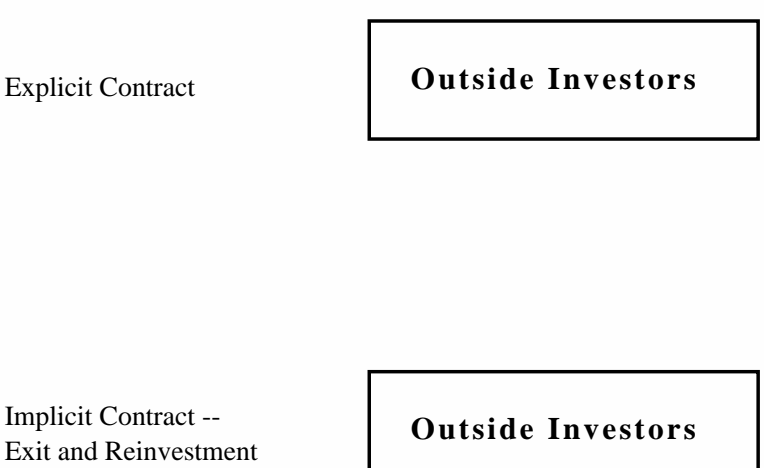

investment in limited partnership

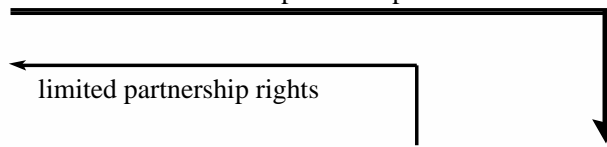

Venture Capitalist

Exit and Reinvestment

Outside Investors

return on investment

invest in future partnerships if return

on prior investment is acceptable 
Figure 3

Implicit and Explicit Contracts

Between Venture Capitalist and Entrepreneur

Explicit Contract

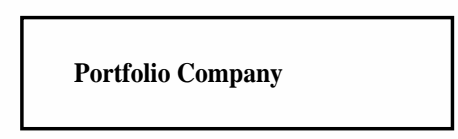

cash + advisory services + reputation

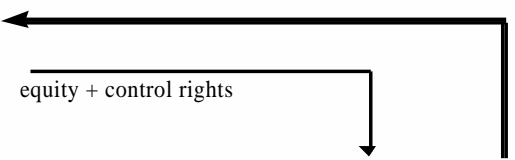

Implicit Contract --

Control Rights

Entrepreneur

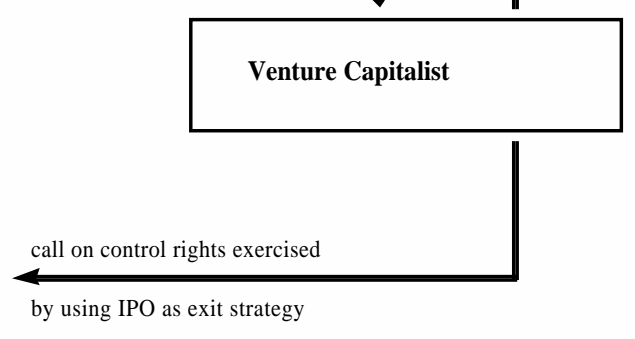

